\title{
Theology in a postmodern culture: ten challenges
}

\author{
G J Rossouw
}

Rand Afrikaans University

\begin{abstract}
The shift from a modern to a postmodern culture which is still in the making brings a new understanding of self and the world with it. Theology therefore has to reflect on the implications and compatibility of this new understanding of the self and the world for a Christian understanding of reality as revealed in the Bible and other relevant texts. In this paper $I$ shall describe some dimensions of this cultural shift that is occurring and then reflect on the challenges and opportunities that they offer to theologians. The dimensions of the postmodern culture discussed in the paper are the broader notion of rationality that the postmodern culture proposes, its broader anthropology, the emphasis on the involvement of both expertise and experience in decisionmaking, and finally the reduction of the world to a 'global village'.
\end{abstract}

\section{INTRODUCTION}

Theology is 'that aetivity by which human beings relate their faith in God (theos) to the patterns of meaning that prevail in any historical period or culture (logos)' (Cox 1984:176).

Culture is the interpretative and coping mechanism of society. It is the way in which people understand themselves, their world, and the appropriate interaction with one another and with the world they live in. The above definition of theology 
rightly suggests that theology is a second order activity that reflects on the meaning of revelation for a specific cultural situation. Any fundamental change in culture therefore necessarily leads to further theological reflection. A theology that pretends to be a timeless and closed system of theological knowledge, unaffected by cultural shifts, runs the risk of becoming obsolete, and is itself a reaction to preceding cultural developments. Isolating theology from culture is a coping strategy by theology - to deal with the challenges that culture poses to a specific theological interpretation of the world.

The shift from a modern to a postmodern (or late-modern, as some prefer to call it) culture, obviously requires new theological reflection. This cultural shift, which is still in the making, brings a new understanding of self and the world with it. Theology therefore has to reflect on the implications and compatibility of this new understanding of the self and the world for a Christian understanding of reality as revealed in the Bible and other relevant texts. In this paper I shall describe some dimensions of the cultural shift that is occurring and then reflect on the challenges and opportunities that they offer to theologians. My intention is not to formulate appropriate theological responses to these challenges and opportunities. Theologians are much better equipped to do that. I shall rather speak as a philosopher who attempts to interpret the culture we live in, and who wishes to invite and involve persons in other disciplines in the conversation - especially theologians, clergy, and other Christians.

\section{DIMENSIONS OF POSTMODERN CULTURE}

Postmodern culture does not abolish modern culture. It is the critical companion or interlocutor of modern culture. It is simultaneously a product of modern culture and a reaction against it. Understanding postmodernity therefore presupposes an understanding of modernity as it developed in the Western world. To achieve the latter, a focus on the rationality that underlies modernity is a good starting-point.

\section{A broader rationality}

Rationality can be defined as the standard that a society requires for making intelligible and meaningful statements about reality. Medieval society, for example, required that statements should be logically coherent as well as compatible with the Christian understanding of reality as defined by the church. This notion of rationality depended on a prior and more fundamental distinction, on which medieval society was built - that is, the distinction between the transcendent and the immanent. In 
this distinction the emphasis was placed on the transcendent. The whole of creation was subordinate to God and his plan for the world. Those institutions and people (the church and its officials) who were regarded as representing God were the ones vested with authority. Every dimension of society was subordinate to the divine plan - as it was presented by the church. The existing social order was portrayed as being a divine order. To challenge the social order was therefore to challenge God's wisdom. Serving the social order was an act of obedience to God (cf Williams 1982:68; Tawney 1962:22-62).

The modern culture that replaced medieval culture rejected the medieval notion of rationality, because the basic distinction upon which the former was built, was that between subject and object (cf Cahoone 1988:18). The subject-object paradigm was judged superior to the transcendent-immanent paradigm, because of its potential to produce more sophisticated and more universally valid knowledge. In this distinction the subject pole is given priority. Subject, however, has been increasingly defined as the independent rational thinking subject. The rationality that results forms this distinction, and its rather narrow definition of subject demands that for any statement about reality to be considered intelligible and meaningful, it should meet two criteria. First, it should be based either on evidence which is evident to every person or which can be checked empirically and independently by any other rational person. Second, any deductions made from that evidence should be done in a logically consistent way, so that any other rational person can similarly repeat the process of deduction.

This notion of rationality stimulated the development of science and technology in an unprecedented way. It led to the sophistication of our knowledge about our natural and social world and to unheard-of control over it. Both its successes and failures contributed to the revision of modern rationality in favour of a broader postmodern rationality. Sophisticated research in quantum physics, for example, indicated that a mechanistic Newtonian worldview, which emphasizes the rational orderliness of our world, is an inaccurate representation of reality. Probability, coincidence, and sheer chaos also have to be accommodated in our understanding of physical reality. It also became increasingly evident that the successes achieved through physical, social, and economic engineering were often achieved at the cost of human alienation and the destruction of our natural and social environment.

The ability of the modern person to deal with these disastrous consequences is severely restricted - if not rendered impossible - by modern rationality. In order to steer the social, physical and economic engineering of our society, commitment to certain values and ends is a precondition. Modernist rationality, however, delegitimizes the discourse on values and ends. It is simply not possible to meet the 
requirements of objective evidence, imposed by modern rationality, when one talks about values, ultimate ends, or the meaning of life. Especially at the peak of the development of modernist rationality, discourse on these matters has been rejected as nonsensical or as mere utterances of emotions - definitely not something to be taken seriously by the modern rational person (cf Ayer 1985:20). The dilemma that surfaced because of this is that, while the inclusion of values, ends and meaning is essential for our survival, the dominant rationality of our culture does not allow for it. Faced with this dilemma, it has gradually become evident that a revision of modernist rationality is inevitable. A broader rationality that will include the socalled non-rational (in terms of modernist rationality) and non-mechanical dimensions of life is needed.

This broader rationality, which is only one of the dimensions of postmodern culture, offers both challenges and opportunities to theology.

\section{- Challenge 1: Critical self-reflection}

The first challenge to theology is to examine critically the impact of modern rationality on the self-understanding and the practice of theology. The aim of this self-examination should be to determine to what extent theology has either overreacted to or identified with the demands of modernist rationality. The churche's removal from the centre of society to just another player on the periphery of society came as a shock to the church, and something theologians were not prepared for. Some therefore reacted on this rejection, by rejecting the bastions of modern rationality. In the words of Harvey Cox (1984:200), 'It [theology] projected its own cramped situation into a statement about God and the world. Not only was theology incompetent and uninterested in politics, science, technology, and the rest, so was God'. This kind of theology found a safe haven in the relative security of the private sphere. The relevance of theology was thus restricted to the domain of personal relations - with little or no meaning for the centre stage of the modern world.

A different reaction to the challenge of modern rationality was to adopt an 'if-you-can't-beat-them-join-them' attitude. Other theologians tried to build a belief system that could formally meet the standards required by modernist rationality. A leap of faith was still needed to accept the Bible as the Word of God but, once that leap was taken, the challenge of modernist rationality could be handled. The content of the Bible was taken as the basic set of data accessible to everyone. A belief system which was true to the data of the Bible was then constructed. Deductions were made from this belief system in a logically consistent way. The result was a rationalistic and logical theological exercise, 
which was timeless and mostly irrelevant for the culture in which it was practiced (cf Hart \& Nielsen 1990:227-228).

Surely the above description is an over-exaggeration and a radical stereotype of what happened in some theological circles. The point, however, is to draw the features of these theologies as distinctly as possible, in order to identify their remnants in current theology. The challenge is, first, to distance oneself critically from modernist rationality and to determine both the reductionist and the liberating potential therein. Second, one must become involved in the discourse on the criteria for a broader rationality. This involvement should not be for the sake of restoring social respect or power for the church and theology, but it should be carried by the conviction that theology has an understanding of reality without which any discourse is impoverished.

\section{- Challenge 2: Involvement in moral discourse}

In Western society the church has always been an important source of moral formation - and no wonder. It is concerned with the ultimate end(s) of life and the moral values and character traits that should guide and socialize the community of believers towards those ends. Modern science, politics and economics have temporarily excluded morality from their discourses and have focused exclusively on the mechanics of the respective fields (cf Sen 1987:4-5). The futility and danger of this exclusion is starting to dawn on us. The growing awareness of the need for a broader rationality, which will include talk on values and ends, offers an open and standing invitation to theologians, clergy and all Christians. The need for political and business ethics is especially pressing and urgent. This opportunity should be seized by believers of all ranks, for the above mentioned reason.

Not all are ready for this opportunity. Many - if not most - have been disempowered by the exclusion imposed on them by modernist rationality (Shriver 1982:124). Clergy, as well as ordinary believers, should be prepared and empowered for the contribution that could be made in this respect. Seizing this opportunity therefore has important implications for the training and re-training of clergy. Greater emphasis should be placed on the clergy's understanding of contemporary culture, its ability to analyse it, and the skills needed to make a propper ethical analysis. The clergy should also be willing to make meaningful and significant use of the human resources in its parishes as the expertise and experience it might lack, are probably present and available in their parishes. $\mathbf{A}$ new style of leadership and communication is needed to tap these resources. 
- Challenge 3: A spirituality of wholeness

The modernist discourse, which favours talk on the mechanics of the world at the cost of a more comprehensive understanding of the world, hampers the ability of people to put whatever they are doing in a bigger context. Inclusion of a moral dimension in any discourse requires exactly this bigger context or picture. Actions are not inherently good or bad, but they are good or bad in relation to some or other end, or to some or other understanding of what a situation is supposed to be. This bigger understanding of reality determines the moral value and status of behaviour, as well as the relative importance of specific behaviour (cf Aristotle 1978:64-74; Hauerwas 1981:10; Leahy 1986:468; and Williams \& Murphy 1992:18).

Christians of all kinds have a unique opportunity in this regard, but there is a big 'IF' involved. If their faith brings them to an understanding of reality - an understanding of the nature, meaning, and value of life, and the lifestyle that fits that understanding of reality, then they can make a valuable contribution to restore a sense of wholeness wherever they are involved (cf Shriver 1982:127). Their faith then fosters a spirituality of wholeness that provides them with the bigger picture, in which the different dimensions of personal and social life find their place and meaning. If, on the other hand, their faith consists of a set of rules - a collection of do's and don'ts - they will not have much to contribute, at least not in a manner that people who do not share their sets of do's and don'ts will be able to comprehend.

- Challenge 4: Narrative theology

Such a spirituality of wholeness depends doubly on a narrative approach to theology. First, the Bible should be approached as a book which offers two complementary stories - the story of the people of Israel, and the story of Jesus - in which a divine perspective on reality is revealed. The variety of teachings, prescriptions, tales, metaphors, or other elements of the Bible should be related to the bigger story and to the purpose of both stories to reveal a Christian understanding of reality (cf Gustafson \& Johnson 1982:319). The Bible and the tradition of reflection that derived from it should therefore be presented as a comprehensive whole that informs believers on a proper attitude to life. Such a theology alone can form the basis for a spirituality of wholeness. Second, to cultivate a spirituality of wholeness, believers need not only understand the story of the Bible, but they also have to relate the stories of their lives, and the stories of the different dimensions of their lives, to the bigger story presented by the Bible. A narrative style of preaching and communication is essential for the 
facilitation of this process. Building a spirituality of wholeness is nothing other than socializing people into the Christian understanding of reality. Stories are very effective for achieving this goal: 'Stories have the capacity not only to inform but also to involve the hearers, draw them into the story, call forth commitment, and evoke ownership of the world and responsibilities embodied in the narratives' (McCoy 1992:60).

\subsection{A broader anthropology}

Another dimension of the postmodern reaction against modernist rationality is the revolt against the restricted notion of the human subject. Modernist rationality has treated the human subject as an independent, rational, thinking subject. Both Nietsche and Freud were forerunners of the postmodern critique on this restrictive anthropology, with their emphasis on the emotional, volitional, and even irrational (or anti-rational) side of human nature. Part of the postmodern culture is a growing consensus that human behaviour is not exclusively motivated by independent rational thinking. The role that socialization, culture, ideology, beliefs, power, emotions, dispositions, et cetera, play in the behaviour of people is acknowledged and accounted for in different practices. In the process of learning or understanding, for example, the focus will no longer be solely on the content of what is to be learned, but due consideration will also be given to those subjective experiences that might have an impact on the learner's ability and willingness to acquire that information (cf Lorsbach \& Tobin 1992; Bruffee 1992:20-22). The current emphasis on the learner in the process of learning, as well as the accent on non-cognitive factors in the field of hermeneutics, both testify to this broader view on human subjectivity. Another example of this phenomenon is the focus on the business culture in the field of business management (cf Deal \& Kennedy 1982). Here the emphasis is on the role that values, symbols, rites, rituals, et cetera have on the behaviour of people in a business environment. This is once again an acknowledgement that business performance is not merely the result of cold rational self-centred thinking, but that other so-called non-rational and supra-personal factors also have a profound impact on the performance of business - and, in fact, are a precondition for sustained excellence in business.

\section{- Challenge 5: Style of communication}

This broader view of human subjectivity challenges the church to a different style of communication. On the negative side, it challenges the church to abandon a style of communication that aims at downloading religious information on 
its members. Conversely, it calls the church both to a style of communication which involves the experiences and expectations of its members, and which appeals to all their facilities and not solely to their intellect. The church has abundant resources for this latter challenge. Through songs, prayers, sacraments, symbols, images, metaphors, stories and worship it can communicate in a way that appeals to the cognitive, emotive, and conative dimensions. The involvement of the experiences and expectations of its members in its communication is a task for which the church is probably not sufficiently prepared. Factors that may impede the church's ability to get this involvement are its hierarchial structure and the dominating role some ascribe to the clergy, or the role that clergy sometimes prefer to play. I do not suggest that all communication in the church should be dissolved into dialogues. One-way communication certainly has a role to play. But there is also much room for the active involvement of other believers in the process of communication. 'Facilitation' and 'negotiation of meaning', both buzzwords in the political and economic world, also have a role to play in the church. Clergy and other communicators in the church should utilize such processes. This, however, demands that they step down from a dominating position and become fellow players in the search for a meaningful Christian life in our contemporary culture. The result promises to have much more credibility for all involved, compared to pre-cooked solutions dished out to an audience. This, once again, has important implications for the training and retraining of clergy. Alternatively, or sometimes even preferably, the services of members of the community of believers who are competent to facilitate such processes can be used. The aim is not to eliminate the theological expertise of the clergy and theologians, but to merge it with the experiences and expectations of the non-theologian and non-clergy believers - in a way that is consistent with a Christian understanding of reality.

* Challenge 6: Character formation

Closely related to this is the challenge to shift the emphasis in spiritual formation from 'What do we believe?' to 'Who are we?' (cf Williams 1986:473). Modernist rationality's emphasis on objective knowledge seduced the church to emphasize the former question at the cost of the latter. The postmodern culture, with its emphasis on the importance of the personal and private dimension of behaviour, offers the church the opportunity to correct this imbalance, and to inverse the order of the two questions. This is not simply a response to a postmodern demand, but is also in accordance with a Christian understanding of human behaviour. Part of that understanding is that Christians develop a new 
identity and character through their faith in God. They develop traits and characteristics that make them steadfast in their behaviour. They make decisions and act in terms of this identity. This process of identity and character formation is not a merely intellectual process, but is a comprehensive process of socialization within a community of believers. Life within the church should be structured in such a way that it offers ample opportunities for this process of socialization and character formation.

\section{Expertise and experience}

A further dimension of the postmodern culture is the emphasis on the fact that expert opinion is not the only factor to be taken into consideration when making decisions. It became increasingly obvious that the most rational, scientific, efficient, and frugal decisions often have unforseen and unintended negative consequences that cause hardship, alienation and suffering for individuals or certain groups in society (cf Walton 1990:347). The realization has dawned that rational action is not necessarily the same as humane action. The postmodern culture insists that those with expert knowledge are not the only ones to whom one should listen when decisions are made. Those who are affected by such decisions also have a valuable and indispensible contribution to make - even if they are considered non-experts or non-literates in terms of modern rationality. Expertise must be enriched and informed by the experience of those on the receiving side of expert opinion. This postmodern emphasis becomes especially clear in the concern for those who have been marginalized in the modern culture - those who were socially rejected by modern society and those who are not fit to compete in modern society. Typical of this development is the concern for the homeless, the hungry, the handicapped, the Third World, persons with Aids, gays and lesbians, et cetera. These and other forms of marginilization should be stopped, reversed and avoided. The strategies for doing this should, however, again not be provided only by the experts, but the victims of such marginalization should be drawn into the discourse as well.

This dimension of the postmodern culture equally poses a couple of challenges to which the church and theologians will have to respond.

\section{* Challenge 7: Concern for the marginalized}

Theology has a long and rich tradition from which it can draw in its response to the challenge to care for the marginalized in society. Liberation theology and the most recent research on the historical Jesus are only two of the recent developments which have again focused attention on the special concern displayed 
in Scripture for the marginalized. The motivation for this intervention on the part of the unfortunate is grounded in the Christian understanding of the value of human life. According to this understanding of reality, God bestows an unconditional dignity and value on all human beings, irrespective of and prior to any personal achievements. God therefore reveals and illustrates through the story of his people and the story of Jesus a special concern for those whose human value and dignity is denied by society - those in danger of dropping out of the care of society, or who have been excommunicated from society (cf Stuhlmueller 1988:19-24). This is demonstrated in the story of Israel through the concern that God shows for the widows, the orphans and the strangers. In the story of Jesus this is demonstrated through his concern for those who were considered as social, economic, cultural, and even religious outcasts of the society in which he lived - for example, the tax-collectors, the poor, and the Samaritans.

In responding to this challenge by the postmodern culture the church is not simply going with the stream, but will be true to its calling. It has a unique contribution and perspective to offer on this issue - a perspective that can enrich the postmodern discourse on marginalization.

- Challenge 8: From being right to doing right

A further challenge offered by this dimension of the postmodern culture is to focus renewed attention on the consequences of theological paradigms and a theological understanding of the world. Theologies and Christian practices that cause systematic or prolonged suffering and degradation can hardly be worthy of the name 'Christian' (cf Hart \& Nielsen 1990:228). A Christian understanding of the world can never be anti-human. On the contrary, it should always be able to claim that it is the best available approach to ensure the fullest development of human potential in all stations of life (cf Küng 1991:89-98; Richard 1988:94-97). Christians of all kinds should therefore not only be sensitive to suffering in general, but should be especially sensitive to the practical consequences that theologial perspectives and belief practices might have. $\mathbf{A}$ kind of faith empiricism is not inappropriate to ensure that orthodoxy is also complemented with orthopraxy.

\section{Global village}

Postmodern culture is both a reaction to, and a result of the modern culture. This is particularly evident in the global dimension of the postmodern culture. Modern technology, and specifically communication technology, brought the different and 
previously isolated parts of the world together in an unprecedented way. It reduced the world to a so-called 'global village'. This shrinking of the world has numerous consequences. Only two will be highlighted here. One, it put an end to the idea and excuse of 'internal' or 'household' problems. Through the media, local and national problems soon become world problems. Retreating to the an excuse of internal problems in which outsiders should not interfere no longer convinces the world community when it comes to human suffering or the violation of basic human rights. South Africa and Somalia are two recent examples that come to mind in this respect. Second, life in the global village also focused attention on pluralities of all kinds - cultural, political, religious, et cetera. There is a growing consensus that no one group or culture has the right to dominate any other culture, and that cultures are not right or wrong, but offer different responses to different problems. The domination of one culture over another is therefore inappropriate. This acknowledgement of pluralities of all kinds is fuelling the debate on whether a respect for plurality necessarily results in cultural relativism, where it is a case of 'everything goes'. If this is not the case, what criterion should be used that can legitimize judgment of - and even intervention in - another culture? These two dimensions of life in the global village offer exciting but also mindbending challenges to theology.

- Challenge 9: Personal, but not private

Part of being a Christian in the postmodern 'global village' will inevitably be the rubbing of shoulders with people of other religions, and with people who reject Christian belief as meaningless, or who do not regard it as being significantly more meaningful than any other religion or world-view. In these situations Christians have two options: They can either retreat into a private sphere and claim that their religious beliefs are private and do not concern other people. This option privatizes faith to the extent that it becomes meaningless to the society in which such a person lives. The other option is to explain and defend their religious understanding of the worid to others who differ from them. The latter option is, to my mind, the only responsible option. If a person loves all people, and is convinced that the Scriptures are 'The Good News' - the perspective on reality that enables one to live the fullest and most meaningful life then one should be able, and indeed have an obligation, to share that perspective with other people (cf Moltmann 1989:3, and Richard 1988:85). When a specific conviction expressed by a Christian is challenged, that person can defend his or her position by relating that conviction to the Christian understanding of reality. A Christian understanding of the world does not contravene a rational understanding of it. On the contrary, it gives a fuller meaning and grea- 
ter depth to a merely rational understanding of the world. Instead of retreating to a private sphere when challenged, it can confidently invite the challenger to try to present an alternative understanding of the world that is more meaningful and comprehensive than the Christian one. Both clergy and other Christians should be encouraged and empowered to share and defend their faith in public when challenged or invited to do so, without denying that it rests on a personal relationship with God.

\section{* Challenge 10: Religious pluralism}

The more serious challenge that life in the 'global village' poses to Christians from all walks of life is to come to terms with the fact of religious plurality. Christians will increasingly have to deal with the perspective that religious convictions have more to do with geography than with belief - that the different world religions are nothing but different cultural responses to the same divine reality (cf Hart \& Nielson 1990:227). Simply dismissing this kind of perspective by quoting the exclusivist texts in the Bible might be good enough for people who reside within the relative security of theological seminaries and churches, but it is not very helpful to those Christians who are exposed to living with people who claim that Christianity is only one of many routes to the Divine Reality. Christians should learn how to relate their understanding of reality (which they regard as the most meaningful one) to their experience that believers of other religions have a similar convinction of their own religious understandings of reality (cf Küng 1991:55-58, 89-98). Coming to terms with this question is by no means an easy task, but simply sidestepping the question will not suffice either. Rather than leaving ordinary Christians to struggle with these questions on their own, theologians and the clergy should guide them, or even better, struggle alongside them.

\section{CONCLUSION}

The church and theology can never identify with any culture or socio-economic order. Neither can they reside outside culture or orders of different kinds. Cultures and orders present both opportunities and dangers for the church and theology. The postmodern culture is no exception. The transition from the modern to the post-modern culture brings the prospect of exciting and challenging theological deliberation with it. The first fruits of this deliberation are already visible - some liberating and long overdue. Signs of being overwhelmed as well as signs of radical reaction against the postmodern culture are, however, also present. The only way to 
limit extremist reactions, and to secure proper responses to the postmodern culture, other than by keeping in touch with the stories of the Bible and the God behind those stories, is by keeping in touch with fellow believers and communities of believers of all different Christian traditions. Ecumenical dialogue has been a valuable instrument in correcting the excesses in theological reactions to modern culture. It might play a similar role in post-modern culture.

\section{Works cited}

Aristotle, 1978. The ethics of Aristotle: The Nicomochaen ethics. Transl by Thokson, J A K. Middlesex: Penguin.

Ayer, A J 1985. Emotivism, in Velasquez, M et al (eds), Ethics: theory and practice, 20-22. Englewood Cliffs: Prentice Hall.

Bruffee, K A 1992. Science in a postmodern world. Change Sept/Oct 1992, pp 1825.

Cahoone, L E 1988. The dilemma of modernity: Philosophy, culture, and anti-culture. Albany: State University of New York Press.

Cox, H 1984. Religion in the secular city: Toward a postmodern theology. New York: Simon and Schuster.

Deal, T E \& Kennedy, A A 1982. Corporate cultures: The rites and rituals of corporate life. Reading, Ma.: Addison Wesley Publishing Company.

Gustafson, J M \& Johnson, E W 1982. The corporate leader and the ethical resources of religion: A dialogue, in Williams, O F \& Houck, J W (eds), The JudeoChristian vision and the modern corporation, 306-329. Notre Dame: University of Notre Dame Press.

Hart, H \& Nielsen, K 1990. Search for community in a withering tradition: Conversations between a Marxist and a Calvinian Christian. New York: University Press of America.

Hauerwas, S1981. A community of character: Towand a constructive Christian social ethic. Notre Dame: University of Notre Dame Press.

Küng, H 1991. Global responsibility: In search of a new world ethic. New York: Crossroads.

Leahy, J T 1986. Embodied Ethics: Some common concerns of religion and business. Joumal of Business Ethics 5, 465-472.

Lorsbach, A \& Tobin, K 1992. Constructivism as a referent for science teaching. NARST News 34/3, September 1992, pp 1-3.

McCoy, C S 1992. Narrative theology and business ethics: Story based management of values, in Williams, O F \& Houck, J W (eds), A virtuous life in business: Sto- 
ries of courage and integrity in the corporate world, 51-72. Lanham: Rowan and Littlefield Publishers.

Moltmann, J 1989. Creating a just future. London: SCM.

Richard, L 1988. Is there a Christian ethics? New York: Paulist Press.

Sen, A K 1987. On ethics and economics. Oxford: Basil Blackwell.

Shriver, D W 1982. What business managers need to know about the clergy, in Jones, D G (ed), Business, religion and ethics, 119-129. Cambridge: Oelgeschlager, Gunn and Hain Publishers.

Stuhlmueller, C 1988. Option for the poor: Old Testament directives, in Pawlikowski, J \& Senior, D (eds), Economic justice: CTU's pastoral commentary on the bishops' letter on the economy, 19-27. Washington: The Pastoral Press.

Tawney, R H 1962. Religion and the rise of capitalism: $A$ historical study (Holland memorial lectures, 1922). Peter Smith: Gloucester.

Walton, R E 1990. Alienation and innovation in the workplace, in Hoffman, W M \& Moore, J M (eds), Business ethics, 347-349. New York: McGraw-Hill.

Williams, O F 1982. Introduction, in Williams, O F and Houck, J W (eds), The Judeo-Christian vision and the modern corporation, 1-21. Notre Dame: University of Notre Dame Press.

-.- 1986. Can business ethics be theological? What Athens can learn from Jerusalem. Joumal of Business Ethics 5/6, 473-484.

Williams O F \& Murphy, P E 1992. The ethics of virtue: A moral theory for business, in Williams, O F \& Houck, J W (eds), A virtuous life in business: Stories of courage and integrity in the corporate world, 9-27. Lanham: Rowan and Littlefield Publishers. 